Bull. Fac. Agric., Cairo Univ.,59 (2008):197-208.

\title{
EFFECT OF BUFFALO AND COW SKIM MILK FLOURIDIZATION ON 2. SOME CHARACTERISTICS OF CASEIN MICELLES, PROTEOLYTIC DIGESTIBILITY AND MICROBIOLOGICAL PROPERTIES
}

\author{
( Received: 3.4. 2008 )
}

\author{
By \\ I. H. I. Abd El-Ghany and F. A. M. Ramadan \\ Dairy Science and Technology Department, Faculty of Agriculture, \\ Cairo University, Giza, Egypt
}

\begin{abstract}
Fluoridated buffalo's and cow's skim milk with different concentration of sodium fluoride $\mathrm{NaF}(5-20$ p.p.m. Fo) and their effect on the characteristics of casein micelles, proteolytic digestibility and microbiological properties were investigated. Added $\mathrm{NaF}$ reduced the weight and size of casein micelles and this effect increased by increasing the concentration of $\mathrm{NaF}$. After cold storage $\left(5^{\circ} \mathrm{C} \pm 1 / 48 \mathrm{hrs}\right)$ the reduction of weight and size of casein micelles of cow's skim milk contained 20 p.p.m. Fo was markedly higher than that of buffaloe's skim milk. Increasing the concentration of $\mathrm{NaF}$ significantly caused increase $(\mathrm{P} \leq 0.05)$ in the rate of proteolytic digestion of buffalo's milk samples by trypsin and commercial (Alphintern ${ }^{\circledR}$ ) enzymes compared with cow's ones. Growth of lactic acid cultures and pathogenic bacteria in buffalo's and cow's skim milk did was not affected by fluoride supplementation.
\end{abstract}

Key words : buffalo's skim milk; casein micelles, lactic acid cultures NaF; pathogenic bacteria, proteolytic digestion, weight and size,

\section{INTRODUCTION}

The element fluorine occurs widely as fluoride. Many studies in different parts of the world have confirmed the close relationship between fluoride and dental caries. Water and food are the main source of fluoride absorbed by the body. (American Academy of Pediatrics,1979, 1986, Elawamry et al., 1989 and El-Gabry and Darwish , 2003).

Addition of fluoride to centralized water supplies is an effective method for improving the dental health of a population. However, benefits of water fluoridation are limited by the lack of centralized water supplies in much of the world and difficulties in controlling dosages for infants and children. The benefits of dietary fluoride have been demonstrated only for infants and children up to the age of 12 (Al-Khateeb et al., 1991, Levy et al., 1995). Milk is a normal component of the diet of this age group. However, not milk but also dairy products are poor sources of fluoride (Garrec and Plebin, 1986 and Hassan et al., 1999). The supplementation of milk with fluoride is an effective alternative to water fluoridation (Davis, 1979; Pakhomoy, 1996, Banoczy, 1997 and Bian et al., 2004 ). The advantages of fluoridated milk include better dosage control and consumption of other nutrients in milk (e.g., calcium, phosphorus and vitamin D) that are necessary for optimum bone and tooth development (Davis, 1975a,b and White 1987). The fluoride content of milk may vary according to the fluoride content of animal feed, species of milk, drinking water, the surrounding environment (e.g. high fluoride content of the atmosphere due to emissions from aluminium smelters). Processing of milk and milk products and supplementation or fortification of milk with fluoride were reported by some authors (Junkkarinen and Kreula, 1976, Maylan and Krook, 1982, Shehata et al., 1985, Gerrec and Plebin, 1986 and Wheeler et al., 
1988a,b). Fluoride in milk exists in two chemical forms: as ionic or free fluoride and bound fluoride. Ionic fluoride refers to fluoride ion still in solution, while bound fluoride refers to the fluoride that has formed a complex with other elements or compounds (calcium or protein for example). In milk, the casein is present primary in the form of colloidal particles (calcium caseinate phosphate complex) $\sim 50-600 \mathrm{~nm}$ in size known as casein micelles. Much researches have focused on the effect of processing conditions such as temperature, $\mathrm{pH}$, ionic strength, addition or removal of minerals and concentration of salt on the molecular weight and size of aggregates (Grufferty and Fox, 1985, Udabage et al., 2000; Anema and Li 2003, Philippe et al., 2005 and Huppertz and Fox, 2006).

The proteolytic digestibility of milk protein is a complex phenomenon that involves significant changes in the structure, function and application of peptides derived from milk protein. These have been extensively studied (Diaz et al., 1996 and Kim et al., 2007). The casein phosphopeptides (CPP) derived from milk caseins by tryptic digestibility associated with amorphous calcium phosphate (ACP) forming stable complexes. These peptides (CPPACP) are able to incorphour fluoride inos. These complexes designated CPPACFP, have the potential to provide superior clinical efficacy in preventing dental caries (Cross et al., 2004 and Kecik et al. , 2008).

Microorganisms vary as regards their tolerance to salt as well as their power of adaptability to salt tolerances. Previous studies have been carried out on the effect of salts on the growth of various microorganisms that are of important to dairy and public health (Perfileve et al. 1982, ElGazzar and Marth, 1991 and Shehata et al., 1997).

However, no cited studies were reported on characteristics of casein micelles, proteolytic enzyme and microbiological evaluation of fluoridated and contaminated buffaloe's skim milk with fluorine. Therefore, the objective of the present study was to evaluate the common levels existed (5-20 ppm $\mathrm{F}$ ) in fluoridated or contaminated buffaloe's skim milk on weight, size of casein micelles, proteolytic digestion and growth of lactic acid cultures and pathogenic bacteria compared with those of cow's skim milk.

\section{MATERIAIS AND METHODS}

\subsection{Materials}

\subsubsection{Milk samples}

Fresh raw bulk buffalo's and cow's milk was obtained separately from the hards of the Fac. Agric., Cairo Univ. Milk samples were separated twice using a cream separator. The residual fat was removed by centrifugation at $3000 \mathrm{rpm}$ for $15 \mathrm{~min}$. at $5^{\circ} \mathrm{C}$.

\subsubsection{Sodium fluoride solution $(\mathrm{NaF})$}

Analytical grade sodium fluoride (Sigma Chemical Co.) was dried and $2.210 \mathrm{~g}$ weight dissolved in distilled deionized water and made to $1 \mathrm{~L}(1000 \mathrm{mg} \mathrm{F} / \mathrm{L})$.

\subsubsection{Enzymes}

\subsubsection{Trypsin}

Pancreatic trypsin (3.0 Anson trypsin unit) was obtained from Nova Nordisk A/ S Denmark .

\subsubsection{Pepsin}

Pepsin cryst $(100 \mathrm{~m} \mu / \mathrm{mg})$ was obtained from Merck, Germany.

2.1.3.3. Alphintern ${ }^{\circledR},($ commercial Enzyme)

Each table contained chymotrypin (300E.A.U) and trypsin (300E.A.U) was obtained from Amoon Pharmacea Trial Industries Co., Cairo, Egypt; under license from Lab Leuroquin France.

\subsubsection{Microorganisms}

\subsubsection{Lactic acid cultures}

Yoghurt culture Lactobacillus acidophilus, Bifido bacterium, Lactobacillus casei and Lactobacillus para casei were obtained from the Dairy Sci. and Technology Dept., Fac. Agric., Cairo Univ.

\subsubsection{Pathogenic microorganisms}

Gram negative( Escherichia coli and Salamonella typhinurium)and gram positive (Staphylococeus aureus and Listeria monacytogenes) were obtained from the Dept. of Agriculture Microbiology Fac. Agric., Cairo Univ.

\subsubsection{Preparation of fluoridated milk}

Buffalo's, cow's skim milk and mixture of the two $(1: 1 \mathrm{v} / \mathrm{v})$ of known added fluoride concentrations $(5,10,15$ and 20 ppm F. $)$ were prepared by the addition of appropriate volumes of aqueous sodium fluoride $(\mathrm{NaF}$ 
1000 ppm $\mathrm{F}_{\text {) }}$ to known volumes of milk with stirring and were left standing for one hour to equilibrate at room temperature $25^{\circ} \mathrm{C}$. The same procedure was used for preparation fluoridated reconstituted skim milk powder $(10 \%)$. The control samples were perpetrated without adding $\mathrm{NaF}$.

\subsection{Methods of analysis}

\subsubsection{Determination of weight and size}

For measuring the average weight and size of the casein particles, the method of Dyatchenko and Voldavento (1953) was followed, The optical density was measured using a Unicam 8625 UV/VIS spectrophotometer (Ati Laicam, England) and read at $545 \mathrm{~nm}$. The casein content of the milk samples was determinated by the Kjeldahl method as modified by Rowland (1938).

\subsubsection{Determination of proteolytic digestibility}

The proteolytie digestibility of milk samples was carried out with the use of trypsin, pepsin and Alphintern ${ }^{\circledR}$ enzymes as described by Datta Roy (1981\&1982). The optical density of $\alpha$-amino nitrogen at 575 $\mathrm{nm}$ was estimated using a Unicam 8625 UV/VIS spectrophotometer (Ati Laicam, England) according to the method of Lee and Takahashi (1966 ).

\subsubsection{Microbiological analysis}

Growth rates of fermented cultures and pathogenic organisms were determined in sterilized fluoridated buffalo's and cow's skim milk (5 to $20 \mathrm{ppm} \mathrm{F}$ ) at $121^{\circ} \mathrm{C} / 5 \mathrm{~min}$. The lactic organisms were inoculated at a concentration of $1.0 \%$ while pathogenic organisms at a concentration of approximaately $10.000 \mathrm{cfu} / \mathrm{ml}$. The inoculated milk was incubated without agitation at $37^{\circ} \mathrm{C}$ for all lactic acid bacteria except yoghurt culture at $40^{\circ} \mathrm{C}$ for 4 to $16 \mathrm{hrs}$. The samples of pathogenic organisms were incubated at $32^{\circ} \mathrm{C}$ to $37^{\circ} \mathrm{C}$ for 1 to 4 days.

\subsubsection{Statistical analysis}

Experiments were repeated in triplicates and each analysis in triplicates. Data were analyzed statistically using the general modal of SAS (Statistical analysis system, 2000) at $5 \%$ level of significance.

\section{RESULTS AND DISCUSSION 3.1. Weight and size of casein micelles}

Table (1) reveals the weight and size of casein micelles of different milk species containing $\mathrm{NaF}$ up to 20 p.p.m $\mathrm{F}$. In control samples, reconstituted cow's skim milk had higher weight and size than other milk samples. This could be attributable to attachment of denatured whey proteins onto the outside K-casein layer of the casein micelles, increasing their hydroyonmic size (Oldfield et al., 2005 and Martin et al., 2007). However adding up to 20 p.p.m. F as $\mathrm{NaF}$ progressively reduced the weight and size of casein micelles of different treated milk samples.

The obtained data show that there was no significant effect of various concentrations of $\mathrm{NaF}$ (5-20 p.p. F) on the weight of casein micelles while there are significant differences between milk species. The reduction of weight was in ordered reconstituted skim milk powder $>$ buffalo's and cow's skim milk 1: $1>$ cow's skim milk $>$ buffalo's skim milk.

As regards the size, it is clear that the casein micelles size of all samples progressively decreased with increasing of $\mathrm{NaF}$ concentration. The analysis of variance showed that there were significant differences $\quad(\mathrm{P} \leq 0.05) \quad$ among the concentrations of $\mathrm{NaF}$ added and milk species. The previous studies showed that changes in the weight and size of casein micelles were related to many factors such as composition of milk, stage of lactation, seasonal variation, individuality, $\mathrm{pH}$ and salt balance (Abd El-Salam et a.l., 1978, Ismail et a.l., 1978, Salama et a.l., 1978a,b Youseff et al., 1983 a,b and Salam et al., 1983).

The casein micelles weight and size of buffaloe's and cow's skim milk containing $\mathrm{F}$ as $\mathrm{NaF}$ (5-20 p.p.m) during storage at $5 \pm 1^{\circ} \mathrm{C}$ for $24-48 \mathrm{hrs}$ are shown in Table (2). Supplementation of $\mathrm{F}$ up to 20 p.p.m. progressively decreased the weight and size of casein micelles during storage at $5 \pm 1^{\circ} \mathrm{C}$ for $24 \mathrm{hrs}$ and lowered by increasing storage period from 24 to $48 \mathrm{hrs}$. The changes in the weight and size of casein micelles could be related to many factors such as added fluoride forms a reversible ionic complex with casein micelles (Beddows, 1982 and Beddows and Blake, 1982). The reversibility of the casein micelles structure and salt 
Table (1): Effect of milk fluoridization (5-20 ppm F as Na F $)$ on the weight and size of casein micelles.

\begin{tabular}{|c|c|c|c|c|c|c|c|c|c|c|c|c|}
\hline \multirow{3}{*}{$\begin{array}{c}\text { Type of } \\
\text { milk }\end{array}$} & \multicolumn{6}{|c|}{ Weight (million units) } & \multicolumn{6}{|c|}{ Size $(\mathbf{n m})$} \\
\hline & \multicolumn{6}{|c|}{ Concentration of F (p.p.m.) } & \multicolumn{6}{|c|}{ Concentration of $\mathbf{F}$ ) (p.p.m.) } \\
\hline & Control & 5 & 10 & 15 & 20 & Mean & Control & 5 & 10 & 15 & 20 & Mean \\
\hline Buffalo's & 640.25 & 638.55 & 629.07 & 625.28 & 619.34 & $630.09^{b}$ & $85.91^{\mathrm{C}}$ & $85.47^{\mathrm{D}}$ & $84.42^{\mathrm{E}}$ & $83.89^{\mathrm{F}}$ & $83.06^{\mathrm{H}}$ & $84.55^{\mathrm{a}}$ \\
\hline Cow's & 522.63 & 513.95 & 509.56 & 507.06 & 505.05 & $511.65^{\mathrm{d}}$ & $70.17^{\mathrm{K}}$ & $68.94^{\mathrm{L}}$ & $68.45^{\mathrm{M}}$ & $68.03^{N}$ & $67.74^{\mathrm{O}}$ & $68.66^{\circ}$ \\
\hline $\mathrm{B}: \mathrm{C}(1: 1)$ & 649.91 & 630.11 & 628.76 & 622.42 & 620.41 & $630.32^{a}$ & $87.20^{\mathrm{B}}$ & $84.54^{\mathrm{E}}$ & $84.41^{\mathrm{E}}$ & $83.46^{\mathrm{G}}$ & $83.23^{\mathrm{H}}$ & $84.56^{\mathrm{a}}$ \\
\hline RSP & 655.08 & 617.02 & 615.51 & 593.36 & 591.27 & $614.45^{\mathrm{c}}$ & $87.92^{\mathrm{A}}$ & $82.80^{\mathrm{I}}$ & $82.59^{\mathrm{I}}$ & $79.92^{\mathrm{J}}$ & $79.32^{\mathrm{J}}$ & $82.39^{b}$ \\
\hline Mean & 616.97 & 599.41 & 595.72 & 587.03 & 584.01 & & $82.80^{\mathrm{a}}$ & $80.44^{b}$ & $79.97^{\mathrm{C}}$ & $78.67^{\mathrm{d}}$ & $78.343^{\mathrm{e}}$ & \\
\hline S.E. & 20.6837 & 18.8378 & 18.9172 & 18.0772 & 17.7889 & & 2.7692 & 2.535 & 2.5287 & 2.4205 & 2.3867 & \\
\hline
\end{tabular}

$\mathrm{RSP}=$ Reconstituted skim milk powder.

Different superscripts $(A, B, C, a, b, c, \ldots)$ at the same column are significantly different $(P \leq 0.05)$.

S.E $=$ Standard Error 
balance change was produced by cooling at $4^{\circ} \mathrm{C}$, (Dalgleish and Law 1989, and Udabage et a.l, 2000). Also, loss of free fluoride in stored milk is a result of its binding to $\mathrm{Ca}^{++}$ released from the protein (Weiczorek et al., 1992). Furthermore, ionic strength increase (i.e. on adding $\mathrm{NaF}$ ) leads to a reduction in the ionic activity of calcium phosphate which causes an increase in solubility and dissociation of calcium phosphate (Walstra 2003).

Statistical analysis in Table (2) reveals that there were significant variations between concentrations of added $\mathrm{NaF}$ and species of milk. Cow's skim milk samples were higher with significant effect $(\mathrm{P} \leq .05)$ than those of buffalo's samples. The reductions of weight and size of cow's milk containing 20 p.p.m. $\mathrm{F}$ as $\mathrm{NaF}$ was $7.2 \%$ compared with $2.6 \%$ in buffalo's samples.

\subsection{Proteolytic digestibility enzymes}

Comparison of digestibility rate by different enzymes of buffalo's and cow's skim milk containing 5-20 p.p.m. $\mathrm{F}^{-}$as $\mathrm{NaF}$ is given in Table (3). The rate of proteolysis is known to depend on the enzyme specifically and the conformation of proteins. Trypsin specifically attacks the carboxy group of lysine and arginine while pepsin specifically attacks the carboxy group of tryptophan, phenylalanine, tyrosine, methionine and leucine. The changes in conformation of milk proteins alter the number of accessible peptide bonds after the rate of proteolysis (Kim et al., 2007 and Qi et al., 2007). The results show that the addition of $\mathrm{NaF}$ enhanced the rate of digestibility by trypsin and commercial enzymes of buffalo's and cow's skim milk at any concentration of $\mathrm{NaF}(5-20 \mathrm{ppm} \mathrm{F}$ as $\mathrm{NaF}$ ) and incubation time (30-60 min.). It also revealed that the significant effect of $\mathrm{NaF}$ was more clear with buffalo samples than those of cows. Furthermore, the presence of $\mathrm{NaF}$ did not improve the rate of peptic digestibility of buffalo and cow samples. The significant differences in the relative digestibility of milk samples attributable to interactions between milk proteins and $\mathrm{NaF}$ may affect the backbone conformations of the protein and the amino acids (AA) between inside and outside of the protein. Therefore, the small amount of $\mathrm{NaF}$ present can probably allow the better exposed functional groups of the AA side chains to enzyme attack. Datta Roy $(1981,1982)$ showed that heating and freezing bring about a drastic changes in the three-dimensional conformation of the milk proteins so as to expose the carboxy group of lysine, arginine and tryptophan, phenylalanine tyrosine methionine for trypsin and pepsin to attack respectively of the milk species (cow, buffalo and goat).

Statistical analysis of these data (Table 3) support the view that the rate of commercial enzyme digestibility of buffaloe skim milk supplemented with $\mathrm{NaF}$ was significantly higher $(\mathrm{P} \leq 0.05)$ than other enzymes.

Therefore, It is evident, that NaF plays a role in the structural organizations of milk protein, which affect the enzymatic liberation of amino acids.

\subsection{Microbiological properties}

Data collected during the growth of pure cultures in fluoridated buffalo and cow skim milk samples (5-20 ppm $\mathrm{F}^{\circ}$ as $\mathrm{NaF}$ ) show that the microbial activity in fluoridated milk was similar to that in normal milk samples (Table4,5).However, acid production by any of the starter culture organisms tested. Nearly similar findings were reported by (Frank and Christein, 1985, Ivanova et al. 1989). Also, in this respect, Rusoff and Koniknoff (1975) reported that fluoridated milk containing the proper levels of fluoride can be used in cheese making without affecting the cheese culture, and no differences were detected in flavor, color or taste. While, Assali and White (1985) evaluated the effect of either 4 or $40 \mathrm{ppm}$ sodium fluoride on fermented dairy products (butter milk, yoghurt, cottage cheese) and stated that the higher concentration of fluoride significantly retarded acid production in the starter cultures and adversely affected the quality of the fermented production. On the other hand, previous reports showed that the rate of growth of lactic acid, probiotic and pathogenic bacteria was affected by othersalts (Minor and Marth 1972, Shehata et al., 1995 and Mohamoud 1997). Hussein (2004) indicated that replacement of sodium chloride with potassium cholride improved the viability of either free cells or encapsulated bifidobacteria. 
Table (2): Effect of milk fluoridization (5-20 p.p.m. Fó) on weight and size of casein micelles during

\begin{tabular}{|c|c|c|c|c|c|c|}
\hline \multirow{3}{*}{$\begin{array}{c}\text { Concentration of } \\
\text { F (p.p.m.) }\end{array}$} & \multicolumn{3}{|c|}{ Weight (million units) } & \multicolumn{3}{|c|}{ Size $(\mathbf{n m})$} \\
\hline & BSM & CSM & Mean & BSM & CSM & Mean \\
\hline & \multicolumn{6}{|c|}{ At zero time } \\
\hline Control & $640.24^{\mathrm{A}}$ & $522.63^{N}$ & $581.43^{\mathrm{a}}$ & $85.91^{\mathrm{A}}$ & $70.17^{\mathrm{L}}$ & $78.04^{\mathrm{a}}$ \\
\hline 5 & $636.55^{\mathrm{C}}$ & $513.92^{\circ}$ & $575.24^{b}$ & $85.47^{\mathrm{C}}$ & $68.93^{\mathrm{M}}$ & $77.20^{\mathrm{b}}$ \\
\hline 10 & $628.07^{\mathrm{G}}$ & $509.06^{\mathrm{P}}$ & $568.81^{\mathrm{c}}$ & $84.42^{\mathrm{G}}$ & $68.45^{\mathrm{N}}$ & $76.43^{d}$ \\
\hline 15 & $625.27^{\mathrm{J}}$ & $807.06^{\mathrm{G}}$ & $566.17^{d}$ & $83.89^{1}$ & $68.02^{\circ}$ & $75.95^{\mathrm{d}}$ \\
\hline 20 & $619.34^{\mathrm{L}}$ & $505.05^{R}$ & $562.19^{f}$ & $83.06^{K}$ & $67.74^{\mathrm{P}}$ & $75.40^{f}$ \\
\hline Mean & $629.89^{b}$ & $462.86^{\mathrm{d}}$ & & $84.54^{b}$ & $61.304^{\mathrm{d}}$ & \\
\hline \multicolumn{7}{|c|}{ After $24 \mathrm{~h}$} \\
\hline Control & $63931^{\mathrm{B}}$ & $49039^{\mathrm{S}}$ & $56485^{\mathrm{e}}$ & $8573^{\mathrm{B}}$ & $6584 Q$ & $7578^{\mathrm{e}}$ \\
\hline 5 & $632.24^{\mathrm{E}}$ & $444.37^{\mathrm{T}}$ & $538.31^{g}$ & $84.85^{\mathrm{E}}$ & $59.22^{\mathrm{P}}$ & $72.03^{\mathrm{g}}$ \\
\hline 10 & $631.17^{\mathrm{F}}$ & $435.47^{\mathrm{u}}$ & $533.52^{\mathrm{h}}$ & $84.69^{\mathrm{F}}$ & $58.42^{\mathrm{S}}$ & $71.55^{\mathrm{h}}$ \\
\hline 15 & $627.25^{\mathrm{H}}$ & $431.82^{\mathrm{v}}$ & $529.53^{j}$ & $84.15^{\mathrm{H}}$ & $57.92^{\mathrm{T}}$ & $71.03^{j}$ \\
\hline 20 & $626.20^{\mathrm{H}}$ & $426.15^{x}$ & $526.18^{1}$ & $84.06^{\mathrm{H}}$ & $57.20^{\mathrm{V}}$ & $70.63^{k}$ \\
\hline Mean & $631.23^{\mathrm{a}}$ & $445.64^{\mathrm{e}}$ & & $84.64^{\mathrm{a}}$ & $59.72^{\mathrm{e}}$ & \\
\hline \multicolumn{7}{|c|}{ After $48 \mathrm{~h}$} \\
\hline Control & $635.02^{\mathrm{D}}$ & $429.37^{\mathrm{W}}$ & $532.19^{\mathrm{i}}$ & $85.21^{\mathrm{D}}$ & $57.60^{\mathrm{u}}$ & $71.40^{\mathrm{i}}$ \\
\hline 5 & $627.87^{\mathrm{HG}}$ & $425.79^{X}$ & $526.83^{\mathrm{k}}$ & $84.22^{\mathrm{H}}$ & $57.12^{\mathrm{v}}$ & $70.67^{\mathrm{k}}$ \\
\hline 10 & $623.34^{\mathrm{K}}$ & $424.71^{Y}$ & $524.83^{\mathrm{m}}$ & $83.63^{\mathrm{J}}$ & $57.28^{\mathrm{v}}$ & $70.45^{1}$ \\
\hline 15 & $619.06^{\mathrm{L}}$ & $413.88^{Z}$ & $516.47^{\mathrm{n}}$ & $83.04^{\mathrm{K}}$ & $55.51^{\mathrm{w}}$ & $69.28^{\mathrm{m}}$ \\
\hline 20 & $617.74^{\mathrm{M}}$ & $407.08^{\mathrm{A}}$ & $512.41^{\mathrm{n}}$ & $82.91^{\mathrm{K}}$ & $54.62^{x}$ & $68.76^{\mathrm{n}}$ \\
\hline Mean & $624.61^{\mathrm{C}}$ & $420.17^{f}$ & $522.38^{\mathrm{c}}$ & $8380^{\mathrm{C}}$ & $56.43^{f}$ & $70.12 c$ \\
\hline General mean & $628.58^{\mathrm{a}}$ & $459.15^{b}$ & & $84.35^{\mathrm{a}}$ & $61.60^{\mathrm{b}}$ & \\
\hline S.E. & 1.2844 & 7.6578 & & 0.1731 & 1.0287 & \\
\hline
\end{tabular}

S.E.

CSM= cow's skim milk

Different superscripts (A,B,C, a,b,c, ..) at the same column are significantly different $(\mathrm{P} \leq 0.05)$.

S.E. $=$ Standard Error 
Table (3) : Effect of milk fluoridization (5-20 p.p.m. F) on the rate of proteolytic digestibity with different enzymes*.

\begin{tabular}{|c|c|c|c|c|c|c|c|c|c|}
\hline \multirow{2}{*}{ Fo as (p.p.m). } & \multicolumn{3}{|c|}{ Trypsin } & \multicolumn{3}{|c|}{ Pepsin } & \multicolumn{3}{|c|}{ Alphintern ${ }^{\circledR}$ (commercial enzyme) } \\
\hline & BSM & CSM & Mean & BSM & CSM & Mean & BSM & CSM & Mean \\
\hline & \multicolumn{9}{|c|}{ At zero time } \\
\hline Control & $0.3800^{\mathrm{T}}$ & $0.6235^{\mathrm{P}}$ & $0.5017^{\mathrm{f}}$ & $0.3800^{\mathrm{A}}$ & $0.6235^{\mathrm{S}}$ & $0.5017^{\mathrm{n}}$ & $0.3800 \mathrm{Y}$ & $0.6235^{\mathrm{U}}$ & $0.5017^{\mathrm{m}}$ \\
\hline 5 & $0.4200^{\mathrm{S}}$ & $0.6650^{\mathrm{O}}$ & $0.5425^{\mathrm{k}}$ & $0.42000^{\mathrm{Z}}$ & $0.6650^{\mathrm{Q}}$ & $0.5425^{\mathrm{m}}$ & $0.4200^{\mathrm{X}}$ & $0.6650^{\mathrm{T}}$ & $0.5425^{1}$ \\
\hline 10 & $0.4300^{\mathrm{S}}$ & $0.6790^{\mathrm{NO}}$ & $0.5520^{\mathrm{k}}$ & $0.4300^{\mathrm{X}}$ & $0.6790^{\mathrm{P}}$ & $0.5522^{1}$ & $0.4300^{\mathrm{X}}$ & $0.6745^{\mathrm{T}}$ & $0.5522^{1}$ \\
\hline 15 & $0.48550^{\mathrm{R}}$ & $0.7055^{\mathrm{MN}}$ & $0.5805^{\mathrm{j}}$ & $0.4855^{\mathrm{T}}$ & $0.7055^{\mathrm{O}}$ & $0.5955^{\mathrm{k}}$ & $0.4855 \mathrm{~W}$ & $0.7055^{\mathrm{S}}$ & $0.5955^{\mathrm{k}}$ \\
\hline 20 & $0.5655^{\mathrm{G}}$ & $0.7805^{\mathrm{L}}$ & $0.6730^{\mathrm{i}}$ & $0.5655^{\mathrm{F}}$ & $0.7805^{\mathrm{K}}$ & $0.6730^{1}$ & $0.5655^{\mathrm{V}}$ & $0.7805^{\mathrm{R}}$ & $0.6730^{j}$ \\
\hline \multirow[t]{2}{*}{ Mean } & $0.4502^{\mathrm{f}}$ & $0.6920^{\mathrm{e}}$ & & $0.4562^{\mathrm{f}}$ & $0.6920^{\mathrm{d}}$ & & $0.4562^{\mathrm{f}}$ & $0.6920^{\mathrm{e}}$ & \\
\hline & \multicolumn{9}{|c|}{ At $30 \mathrm{~min}$. } \\
\hline Control & $0.7290^{\mathrm{M}}$ & $0.8045^{\mathrm{L}}$ & $0.7667^{\mathrm{h}}$ & $0.524^{\mathrm{W}}$ & $0.7705^{\mathrm{L}}$ & $0.6472^{j}$ & $0.9505^{\mathrm{G}}$ & $1.060^{\mathrm{O}}$ & $1.0052^{\mathrm{j}}$ \\
\hline 5 & $0.8020^{\mathrm{L}}$ & $0.990^{\mathrm{H}}$ & $0.8960^{\mathrm{g}}$ & $0.532^{\mathrm{V}}$ & $0.8120^{\mathrm{S}}$ & $0.6720^{\mathrm{i}}$ & $0.9705^{\mathrm{P}}$ & $0.0825^{\mathrm{N}}$ & $1.0265^{\mathrm{hs}}$ \\
\hline 10 & $0.9490^{\mathrm{JK}}$ & $1.0235^{\mathrm{H}}$ & $0.9862^{f}$ & $0.552^{\mathrm{U}}$ & $0.8235^{\mathrm{I}}$ & $0.6877^{\mathrm{h}}$ & $1.1235^{\mathrm{M}}$ & $1.2225^{\mathrm{K}}$ & $1.1730^{\mathrm{g}}$ \\
\hline 15 & $0.9690^{\mathrm{JI}}$ & $1.050^{\mathrm{EF}}$ & $1.0095^{\mathrm{f}}$ & $0.623^{\mathrm{S}}$ & $0.8435^{\mathrm{H}}$ & $0.7333^{\mathrm{g}}$ & $1.1720^{\mathrm{L}}$ & $1.249^{\mathrm{J}}$ & $1.2105^{\mathrm{f}}$ \\
\hline 20 & $1.3430^{\mathrm{DE}}$ & $1.1015^{\mathrm{cq}}$ & $1.1177^{\mathrm{e}}$ & $0.711^{\mathrm{N}}$ & $0.8880^{\mathrm{F}}$ & $0.7995^{\mathrm{d}}$ & $1.4640^{\mathrm{E}}$ & $1.4315^{\mathrm{G}}$ & $1.4477^{\mathrm{c}}$ \\
\hline \multirow[t]{2}{*}{ Mean } & $0.9166^{\mathrm{d}}$ & $0.9939^{c}$ & & $0.588^{f}$ & $0.8275^{\mathrm{f}}$ & & $1.1361^{\mathrm{d}}$ & $1.2091^{\mathrm{C}}$ & \\
\hline & \multicolumn{9}{|c|}{ At $60 \mathrm{~min}$. } \\
\hline Control & $0.9295^{\mathrm{K}}$ & $1.074^{\mathrm{GH}}$ & $1.0017^{\mathrm{f}}$ & $0.6215^{\mathrm{S}}$ & $0.8525^{\mathrm{G}}$ & $0.7370^{\mathrm{f}}$ & $1.3390^{\mathrm{I}}$ & $1.4470^{\mathrm{F}}$ & $1.3932^{\mathrm{e}}$ \\
\hline 5 & $1.0425^{\mathrm{GH}}$ & $1.2610^{\mathrm{C}}$ & $1.1517^{\mathrm{d}}$ & $0.6580^{\mathrm{R}}$ & $0.8940^{\mathrm{E}}$ & $0.7760^{\mathrm{e}}$ & $1.3510^{\mathrm{I}}$ & $1.4680^{\mathrm{E}}$ & $1.4095^{\mathrm{d}}$ \\
\hline 10 & $1.1615^{\mathrm{D}}$ & $1.2610^{\mathrm{C}}$ & $1.2112^{\mathrm{c}}$ & $0.7540^{\mathrm{M}}$ & $0.9130^{\mathrm{D}}$ & $0.8337^{\mathrm{c}}$ & $1.3860^{\mathrm{H}}$ & $1.4945^{\mathrm{D}}$ & $1.4403^{\mathrm{c}}$ \\
\hline 15 & $1.2345^{\mathrm{C}}$ & $1.3315^{\mathrm{B}}$ & $1.2830^{\mathrm{b}}$ & $0.8095^{\mathrm{J}}$ & $0.9295^{\mathrm{C}}$ & $0.8695^{b}$ & $1.4540^{\mathrm{EF}}$ & $1.5735^{\mathrm{C}}$ & $1.5137^{\mathrm{b}}$ \\
\hline 20 & $1.4240^{\mathrm{A}}$ & $1.3490^{\mathrm{B}}$ & $1.3865^{\mathrm{a}}$ & $0.9420^{\mathrm{B}}$ & $1.0310^{\mathrm{A}}$ & $0.9865^{\mathrm{a}}$ & $1.9775 \mathrm{~A}$ & $1.8225^{\mathrm{B}}$ & $1.8000^{\mathrm{a}}$ \\
\hline Mean & $1.1584^{\mathrm{b}}$ & $1.2553^{\mathrm{a}}$ & $1.2068^{\mathrm{a}}$ & $0.7571^{\mathrm{C}}$ & $0.9240^{\mathrm{a}}$ & $0.8405^{\mathrm{a}}$ & $1.5015 \mathrm{~b}$ & $1.5612 \mathrm{~A}$ & $1.5314^{\mathrm{a}}$ \\
\hline General mean & $0.8417^{\mathrm{b}}$ & $0.9797^{\mathrm{a}}$ & & $0.6005^{b}$ & $0.8138^{\mathrm{a}}$ & & $1.0312^{\mathrm{b}}$ & $1.1534^{\mathrm{s}}$ & \\
\hline S.E. & 0.0598 & 0.0458 & & 0.0279 & 0.0202 & & 0.0870 & 0.0698 & \\
\hline
\end{tabular}

* As optical density at $570 \mathrm{~nm}, \quad$ BSM= Buffalo's skim milk

$\mathrm{CSM}=$ Cow's skim milk

Different superscripts $(A, B, C, a, b, c, \ldots)$ at the same column are significantly different $(\mathrm{P} \leq 0.05)$.

S.E. $=$ Standard Error. 
Table (4): Effect of sodium fluoride supplementation of milk (5-20 p.p.m F 5 ) on the growth of some lactic acid bacteria.

\begin{tabular}{|c|c|c|c|c|c|c|c|c|c|c|c|}
\hline \multirow{2}{*}{ F as (p.p.m.) } & \multirow{2}{*}{$\begin{array}{c}\text { Incubation time } \\
\text { (hr) }\end{array}$} & \multicolumn{2}{|c|}{ Yoghurt culture } & \multicolumn{2}{|c|}{ L. acidophilus } & \multicolumn{2}{|c|}{ B. bacterium } & \multicolumn{2}{|c|}{ L. casei } & \multicolumn{2}{|c|}{ L. para casei } \\
\hline & & BSM & CSM & BSM & CSM & BSM & CSM & BSM & CSM & BSM & CSM \\
\hline \multirow{2}{*}{ Control } & 4 & + & + & + & + & + & + & + & + & + & + \\
\hline & 16 & + & + & + & + & + & + & + & + & + & + \\
\hline \multirow{2}{*}{5} & 4 & + & + & - & - & - & - & + & - & + & - \\
\hline & 16 & + & + & + & + & + & + & + & + & + & + \\
\hline \multirow{2}{*}{10} & 4 & + & + & - & - & + & + & + & - & + & - \\
\hline & 16 & + & + & - & - & + & + & + & - & + & - \\
\hline \multirow{2}{*}{15} & 4 & + & + & + & + & + & + & + & + & + & + \\
\hline & 16 & + & + & - & - & - & + & - & - & - & - \\
\hline \multirow{2}{*}{20} & 4 & + & + & - & - & - & + & - & - & - & - \\
\hline & 16 & + & + & + & + & + & + & + & + & + & + \\
\hline
\end{tabular}

Buffalo's skim milk

CSM= Cow's skim milk.

- = No growth.

Table (5): Effect of sodium fluoride supplementation of milk (5-20 p.p.m. Fo) on the growth of some pathogenic bacteria

\begin{tabular}{|c|c|c|c|c|c|c|}
\hline \multirow{2}{*}{$F^{\prime}$ as (p.p.m.) } & \multirow{2}{*}{ Species of milk } & \multicolumn{2}{|c|}{ Gram negative bacteria } & \multicolumn{3}{|c|}{ Gram positive bacteria } \\
\hline & & E. coli $*$ & $\begin{array}{c}\text { Salmonella** } \\
\text { tunhinurium }\end{array}$ & Staphylococcus *aureus & & \\
\hline \multirow{2}{*}{ Control } & BSM & +++ & +++ & + & +++ & (2) \\
\hline & CSM & + & + & + & +++ & (4) \\
\hline \multirow{2}{*}{5} & BSM & +++ & +++ & $+\frac{T}{+++}$ & +++ & (2) \\
\hline & CSM & + & + & + & +++ & (4) \\
\hline \multirow{2}{*}{10} & BSM & +++ & +++ & +++ & ++ & (4) \\
\hline & CSM & + & + & + & +++ & (4) \\
\hline \multirow{2}{*}{15} & BSM & +++ & $\begin{array}{l}++ \\
++\end{array}$ & +++ & ++ & (4) \\
\hline & CSM & + & + & - & +++ & (4) \\
\hline \multirow{2}{*}{20} & BSM & +++ (gas) & ++ & +++ & ++ & (4) \\
\hline & CSM & + (gas) & + & + & +++ & (4) \\
\hline
\end{tabular}

$+++=$ Strong gro 
To conclude, the species of milk and the concentration of $\mathrm{NaF}$ will lead to differences in growth behavior of organisms studied and consequentially affected the microbiological quality of fluoridated milk. So, the ambient consideration of the healthy nutritional and technological characteristics make sodium fluoride supplementation a very attractive process in dairy industry.

\section{REFERENCES}

Abd El-Salam M.H., Osman Y.M. and Nagmoush M.R.(1978). Comparative study of composition of casein micelles from buffalo's and cow's milk. Egyptain J. Dairy Sci., 6:1-8.

Al-Khateeb T.L., Al-Marasafi A.I., Bastawi A.A. and Darwish S.K. (1991). Report on: Prevention of dental caries through fluoridation of drink water in Saudi Arab King Abdul Aziz University.p1-110.

American Academy of Pediatrics (1979). Public health: Facts: Fluoride drinking water, 63:150-152.

American Academy of Pediatrics (1986). Committee on nutrition; fluoride supplementation. 77: RE 6069-6071.

Anema S.G., and Li, Y. (2003). Association of denatured why proteins milk casein micelles in heated reconstituted skim milk and its effect on casein micelles size. J. Dairy Res. 70:73-83.

Assali K.S., and White C.H. (1985). Effect of milk fluoridization on fermented dairy products. J. Dairy Sci., Suppl. 68:D44.

Banoczy J. (1997). Milk fluoridation: an alternative method for caries prevention. Fluoride 30:116-117.

Beddows C.G. (1982). The status of fluoride in bovine milk. I. Fluoride in cold milk. J. Food Technology. 17:55-62.

Beddows C.G., and Blake C. (1982). The status of fluoride in bovine milk. II.The effect of various heat treatment processes. J. Food Technology. 17:63-70.

Bian J.Y., Wang W.H. Wang W.J. Romg W.S., and Lo C. (2004). Effect of fluoridated milk on caries in primary teeth: 21-mouth results. J. EvidenceBased Dental Practice, 3:241-245.

Cross K.J., Huqu N.L.,Stanton D.P., Sum M. and Reyolds E.C. (2004). NMR studies of a novel, calcium, phosphate and fluoride delivery vehicle $-\alpha \mathrm{s}_{1}$-casein (59-79) by stabilized amorphous calcium fluoride phosphate monocoplexes. Biomaterials 25:5061-5069.

Dalgleish D.G., and Law A.J.R. (1989). pH in diced dissociation of bovine casein micelles II-Mineral solubilization and its relation to casein release. $\mathrm{J}$. Dairy Res. 56:727-735.

Datta Roy D. (1981). Proteolysis of milk from different species by tryptin in vitro. Milchwissenschaft. 36:360362.

Datta Roy D. (1982). Effect of heating and freezing on the peptic proteolysis of cow milk. Milchwissenschaft. 37:461-462.

Davis J.G. (1975a). Fluoridised milk for children-Part I. Dairy Industries J. 40:7-10.

Davis J.G. (1975b). Fluoridised milk for children. Part II. Dairy Industries J. 40:48-51.

Davis J.D. (1979). Fluoridised milk as an alternative to water fluoridation. Milchwissenschaft. 34:721-725.

Diaz G., Gouldsworthy A.M. and Leaver J. (1996). Identification of particles released from casein micelles by limited trypsinolyses. J. Agric. Food Chem. 44:2517-2522.

Dyatchenko P.F., and Voldavento I.N. (1953). Determination of the size of colloidal particles and molecular weight of casein by light scattering. Kolloidzh. 14.338. Cited from Ramadan, F.A.W. (1983). Effect of Some Treatment of Buffaloe's Milk Casin Particles. M.Sc. Thesis. Fac. Agric., Cairo Univ.

El-awamry Z.K., Hussan S.A. and Hamza A.S.C. (1989). The use of some Egyptian medicial plants as a natural and safe source of fluoride to protect children dental caries. Annals Agric. Ain Shams Univ. Cairo, 43:561-574. 
El-Garby E.K., and Darwish S.S. (2003). Effect of fluoride content of diet on dental and periodontal diseases. Egypt. J. Food Sci., 31:259-579.

El-Gazzar F., and Marth E.H. (1991). Listeria monocytogenes and listeriosis related to milk, milk products and dairy ingredients: A review. Literca monocytogenes, Listeiosis and response of the pathogen to environmental condition. Milchwissenschaft. 46:14-20.

Frank J.F., and Christein, G.L. (1985). Microbiological and flavor evaluation of fluoridated milk. J. Food Protection. 48:799-802.

Gerrec T.P., and Plebin R. (1986). The concentration of fluorine in different dairy products made from contaminated milk. Sci. Total Environ. 50:183-190.

Grufferty M.B., and Fox P.F. (1985). Effect of added $\mathrm{NaCl}$ on some physicochemical properties of milk. Ir. J. FDSI, Technol. 9:1-9.

Hassan S.A., El-awamry Z.K. and Hamza A.S. (1999). Dietary fluoride intake from infants and its compensation from some Egyptian foods to avoid dental caries. Arab Univ. J. Agric. Sci. Ain Shams Univ. 7:79-96.

Huppertz T and Fox, P.F. (2006). Effect of $\mathrm{NaCl}$ on some physico-chemical properties of concentrated bovine milk. International Dairy J. 16:11421148 .

Hussein S.A., (2004). Effect of sodium chloride and potassium chloride on the growth and activity of microentrappled and free cells bifodobacterium. Pro. The $9^{\text {th }}$ Egyptian Conf. for Dairy Sci., Tech. 297-304.

Ismail A.A., Youssef A.M., Salama F.A. and Daoud S.M. (1978). The physicochemical properties of the colloid in buffalo milk II-The salt balance. Egyptian J. Dairy Sci., 6:153-163.

Ivanova K., Velichkova E. Gaioladzhieva P. Bogdanova Y.A. and Neddelchev M.N. (1989). Flouridation of children's milk. Khranitelna
Promishlenost (sofia), 38:29-31. Cited from D.S.A, 1991:6293.

Junkkarinen L., and Kreula M. (1976). On the metabolism of fluoride by cows on protein- free and normal feed. Mejjerililellinen Aikakausk irja. Cited from D.S.A. 1977:1127.

Kecik D., Cehreli B., Sar C. and Unver B. (2008). Effect of acidulated phosphate fluoride and casein phosphopeptide-amorphous calcium phosphate application on shear bond strength of orthodontic brackets. The angle orthodontist. 78:129-133.

Kim S.B., Ki K.S., Khan M.A., Lee W.S., Lee H.J., Ahn B.S. and Kim H.S. (2007). Peptic and tryptic hydrolysis of native and heated whey protein to reduce its antigenicity. J. Dairy Sci., 90:4043-4050.

Lee Y.P., and Takahashi T. (1966). An improved calorimetric determination of amino acid with the use of ninhydrin. Analytical Chemistry. 14:71-77.

Levy S.M., Kohout F.J., Guha-Chowdhury N., Kiristy M.C., Heilman J.R. and Wefel J.S. (1995). Infants fluoride from drinking water alone and from water added to formula beverages and food. J. Dent Res. 74:1399-1402.

Martin G.J.O., Williams R.P.W. and Dustan D.E. (2007). Comparison of casein micelles in raw and reconstituted skim milk. J. Dairy Sci., 90:45434551.

Maylan G.A., and Krook L. (1982). Milk production cow's exposed to industrial fluoride pollution. J. Toxicology and Environment Health 10:473-474.

Minor T.E. and Marth, E.H. (1972). Loss of viability by S.aureus in acidified media; II-Inactivation by acids in combination with sodium cholide, freezing and heat. J. Milk Food Technology 35:348352.

Mohamoud H.M.A. (1997). Influence of sodium chloride and $\mathrm{pH}$ on the growth of Listeria monocytognes. Alex. J. Agric Res. 42:27-33.

Oldfield D.J., Taylor M.W. and Singh. (2005). Effect of preheating and 
other process parameters on whey protein reactions during skim milk powder manufactures. Int. Dairy J. 15:501-511.

Pakhomoy K. (1996). Milk fluoridationBackground. Oral health. World Health Organization. Geneva.P 234237

Perfileve G.D., Gudkov A.V. and Grigorov N.I. (1982). Growth of lactic acid bacteria in relation to the content of trace elements in medium. Cited from D.S.A. 48:57.

Philippe M., Le Gaet Y. and Gaucheron F. (2005). The effect of different cations on the physicochemical characteristics of caseins micelle. Food Chemistry. 9:673-683.

Qi W., Su.R.X., He Z.M., Zhang Y.B. and Jin F.M. (2007). Pepsin-induced changes in the size and molecular weight distribution of bovine casein during enzymatic hydrolysis. J. Dairy Sci., 90:5004-511.

Rowland S.J. (1938). The determination of nitrogen distribution in milk. J. Dairy Res. 9:42-47.

Rusoff L.L., and Konikoff B.S. (1975). Fluoridation of milk and dairy products. Xth Int. Congr. Nut., Kyoto, Japan.P 101-105.

Salam A. E., Youssef A.M. and Fetma A.S. (1983). Seasonal variations in the physico-chemical properties of cow's milk. Egyptian J. Dairy Sci., 11:183188.

Salama F.A., Ismail A.A. Youssef A.M. and Daoud S.M.C. (1978b). The physicochemical properties of the colloidin buffalo milk I-pH. Size of casein micelles and opacity. Egyptian J. Dairy Sci., 6:143-151.

Salama F.A., Youssef A.M. and El-Shobary M.A.C. (1978a). Aggregation, diameter, and weight of particles in model systems of casein and casein paracaseins. Egyptian J. Dairy Sci., 6:125-134.

SAS User's Guide Statistical Vresion 8.0 (2000). SAS Institute Inc., Cary, NC, U.S.A.
Shehata A. E., Gaafar A.M. and Moustafa G.A.C. (1995). Growth and survival of enterotoxigenic $S$. aureus in Kariesh cheese. Proc $6^{\text {th }}$ Egyptian Conf. Dairy Sci\&Tech, 155-165.

Shehata A.E., Gaafar A.M. and Moustafa G.A.C. (1997). Viability of enterotoxigenic Staphylococcus aureus in Domiati cheese. Egyptian J. Dairy Sci., 25:135-148.

Shehata A., Ibrahim J.A. and Shabaan A.A. (1985). Effect of industrial pollution on mineral content of cow's and buffaloe's milk. Fluorine, Calcium and Phosphorus. Assiut Veterinary medical J. 13:223-228

Udabage P., Makinnon I.R., and Augustin M.A. (2000). Mineral and casein equilibra in milk: Effect of added salts and calcium-chelating agents. J. Dairy Res. 67:361-370.

Walstra P. (2003). Physical chemistry of foods. New York: Marcel Dekker Inc.P 252-270.

Wheeler S.M., Mckay B., and Nguyen M.H. (1988a). The effect of evaporation and spray-drying upon total and ionic fluoride concentration in milk. The Australin J. Dairy Technology 43:15.

Wheeler S.M.L., Turner A.D. and Macfarlance J. (1988b). Comparison of four methods used to measure total fluoride and one method for ionic fluoride in bovine milk, using the fluoride ion-selected electrode. The Australin J. Dairy Technology $43: 21-26$.

White C.H. (1987). Milk, milk products and dental health. J. Dairy Sci., 70:392396.

Wieczorek P., Sumujlo D., Chlubek D. and Machoy Z. (1992). Interaction of fluoride ions with milk proteins studied by gel filtration. Fluoride. 25:171-174.

Youssef A.M., Salama F., Ismail A.A. and Abou El-Enein S.M. (1983a). Changes in the colloidal state and stability of milk during storage. III. Effect of salt. Egyptian J. Dairy Sci., 11:101-110. 
Youssef A.M., Salama F.A., Salam A.E. and

El-Dakhakhny E.A. (1983b).

Physicochemical properties of individual cow's milk during lactation period. I- Physical properties. Egyptian J. Dairy Sci., 11:189-195.

\section{تأثير إضافة الفلوريد للبن الفرز الجاموسى والبقرى \\ ثانيا: على بعض خواص جسيمات الكازين والتحلل البروتيني والصفاتئ والئري الميكروبيولوجية}

إسماعيل حسين إسماعيل عبد الغنى- فاطمة على متولي رمضان

قسم علوم وتكنولوجيا الألبان ـ كلية الزراعة ـ جامعة القاهرة ـ الجيزة - مصر

\section{ملخص}

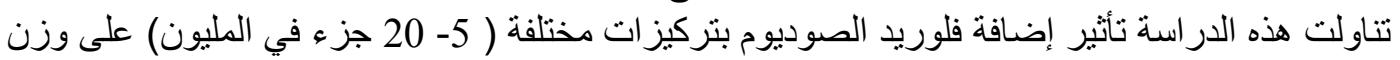

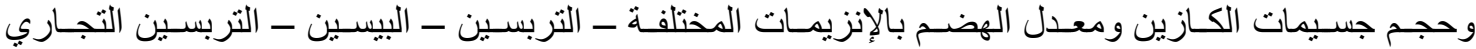

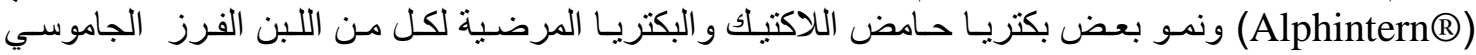

$$
\text { وأوضحت الدري. }
$$

أدت إضافة فلوريد الصوديوم بـالتركيزات المختلفة إلى كل من اللبن الفرز الجاموسي و البقري و الخليط

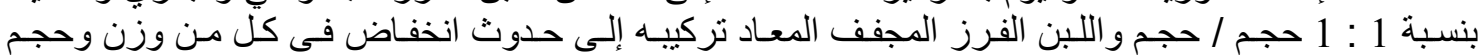
جسيمات الكازين - وكان هذا التاثير اكثر وضوحا في اللبن الفرز الفئ المعاد تركيبه بالمقارنة بالألبان الاخري.

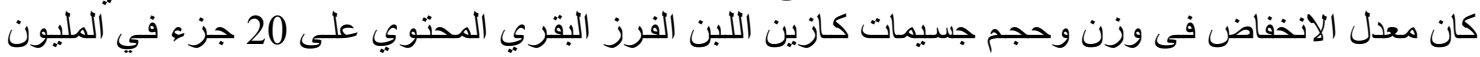

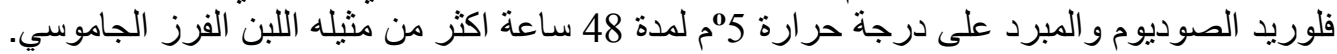

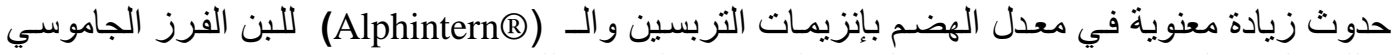

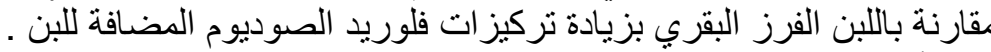

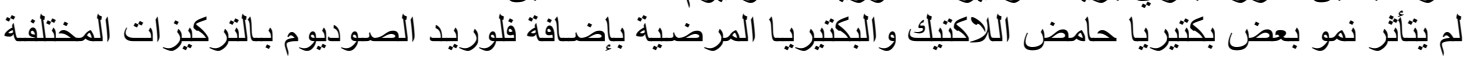
لكل من اللبن الفرز الجاموسي و البقري.

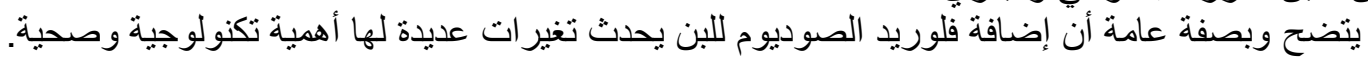

المجلة العلمية لكلية الزر اعة - جامعة القاهرة - المجلد (59) العدد الثالث (يوليو 2008):196-208 